INDEPENDENT JOURNAL OF MANAGEMENT \& PRODUCTION (IJM\&P)

\title{
PERFORMANCE INDICATORS APPLIED TO BRAZILIAN PRIVATE EDUCATIONAL INSTITUTIONS
}

\author{
Átila de Melo Lira \\ Universidade Paulista, Brazil \\ E-mail: atilalira@hotmail.com \\ Irenilza de Alencar Naas \\ Universidade Paulista, Brazil \\ E-mail: irenilza@gmail.com
}

Submission: $21 / 08 / 2014$

Revision: 09/09/2014

Accept: 21/10/2014

\section{ABSTRACT}

Initially focused on for-profit companies the Balance Scorecard (BSC) has been adopted by many organizations with different objectives, such as higher education institutions (HEls). However, it is not clear if the adoption of the BSC model is appropriate, or yet is hard to perceive how HEls have modified and implemented this tool for evaluating educational institutions, public or privates, in Brazil. This study aims to fill the gap existent in the context of using the BSC in organizations. We intend to demonstrate how these organizations use performance indicators to measure their primary activities. A quantitative and exploratory study was developed from the analysis of performance indicators found in the web sites to Brazilian universities. A total of 91 Brazilian private universities evaluation process were reviewed. Even with a considerable amount of private HEls there are few that have performance indicators guided by numerical and statistical data covering its main activities which is a concern for their managers in terms of managerial control.

Keywords: Balanced scorecard; performance indicators; private higher education institution. 
DOI: 10.14807/ijmp.v6i2.261

\section{INTRODUCTION}

The activities performed in an organization require constant monitoring and evaluation, which requires managers to use methods for this purpose. The Balanced Scorecard (BSC), is one of the most used tools for the measurement and analysis of organizational performance. This approach assesses the different perspectives involved in the business dynamics (KAPLAN; NORTON, 1997).

Originally proposed by Kaplan e Norton (1992), the BSC has spread quickly and consistently in the business scene. Steele (2001) credits this development to the need of proper guidance for making decisions. In turn, Kaplan e Norton (1996) argues that the rapid expansion of BSC derives from the ineffectiveness of previous management strategies.

Supporting these arguments Campos (1998) states that only the financial and accounting assessments are not sufficient to determine the performance of an organization, and can easily provide misleading on improving business outputs. Then it appears that the contributions proposed by Kaplan e Norton (1992) overcame the traditional financial-accounting theory of evaluation urging scholars and strategists to review some paradigms and envision new ways to assess organizational performance.

This study, which presents itself as the first step of a much larger research, aims to amend the gap in the subject that deals with the application of the BSC in Brazilian HEls, through the development of a research that uses performance indicators to assess activities as research and extension, teaching-learning, institutional management, financial management and quality of communication services.

\section{LITERATURE REVIEW}

\subsection{Balanced scorecard}

Thus, the BSC offers organizations a valuable mechanism for the translation of strategy into objectives, measures and targets. Kaplan e Norton (1992) argues that the BSC transcends simple strategy formulation making it a true intervention mechanism. In designing these authors the BSC reflects the balance between goals 
of short and long term, between financial and non-financial measures, and between the internal and external performance perspectives KAPLAN; NORTON, 1996).

The BSC model proposed by Kaplan e Norton (1992) supports the view of the organization from four key perspectives, namely, finance, customers, internal processes and learning/growth. For management purposes, metrics (scorecards) are developed, and data is collected to evaluate each of these perspectives.

During the process of evolution, the idea of BSC is being modernized plus new features. One of these contributions was proposed Macstravic (1999) pointed out that when the BSC is a way to translate the company vision real strategy, providing feedback enabling the learning activities of their components. Another literature Steele (2001) provides the BSC concept of the guiding element of conscious decision- making process, stating that this tool translates the transmission of the approach through a set of integrated measures.

In summary, the BSC is a necessary good for organizations, as it says Kaplan e Norton (1992) because it provides more robust decision-making, increased financial and administrative control of activities and inter-relationship between the various constituent processes across organizational, putting strategy at the center of the management process (KAPLAN; NORTON, 1992).

In Brazil, we can from the contributions of Papini et al., (2011). In a study aiming to compare the performance indicators used by the metallurgical industry sector, the authors, using the BSC methodology, highlighted the potential for improvement and could propose specific changes that allowed the improvement of company management. In this investigation, the authors emphasize the importance of using effective measurement mechanisms to foster the sound management of an organization.

Souza and Albuquerque (2012) go further to show that the BSC can also be used to measure intangible assets. In their research, the authors applied this management strategy to demonstrate the importance of knowledge management in the context of organizations, which are able to provide a competitive advantage. This character was also highlighted in the study by Prado et al. (2013) on accounting controllership. 
Finally, in a study of practical application in a company providing accounting services, Vieira and Petri (2014) reaffirm the need to adapt the organizational context before applying the BSC. The authors proposed the formulation of a sustained strategic map in four perspectives: customers; internal processes and learning; and growth, which resembles the traditional dimensions proposed by Kaplan and Norton (1992), however adapted to the reality of the studied company.

\subsection{The application of the balanced scorecard in HEls}

The fundamental principle presented by the BSC, ie, a combination of measures of strategy, mission and performance, is not new in the context of HEls. The first evidence of the use of this tool in the university environment, were designed by O'Neil et al. (1999). These authors argue the need for application of the BSC in this environment, since educational institutions are increasingly held accountable for the results of the services that offer.

The authors recognize that HEls designed by them as "organized anarchy", represent the kind of organization where there is a greater difficulty for the BSC, because there seems to be a strong resistance and skepticism on the part of scholars on the possibility of introducing quantitative measures in the evaluation of how these institutions are effective (O'NEIL et al., 1999).

Historically, the performance indicators adopted by HEls did not have an image of situation of the institution as a whole. These indicators were unable to visualize the organizational dimensions under the administrative standpoint, neglecting aspects such as mission, vision and strategic direction of the institution, as highlighted Philbin (2011).

This scenario proved opportune for the introduction of the BSC in the context of HEls. This new tool allowed the higher education institutions a broad approach to their processes not sticking to simple accounting-financial measures. Kaplan and Norton (1992) explain that this tool allows you to find different ways to help the institution to achieve the objectives previously set in the strategic planning.

The contributions offered by the BSC to the HEls can be evidenced through some elaborate constructs within this theme. It is worth mentioning the study of Lima, Soares and Lima (2013). These authors point out that adapting the BSC to the 
complex world of HEls is a big challenge, much of this difficulty is related to skepticism own managers, so the complexity is not the strategy, but in management.

Aware of the need that companies have to achieve improvement in organizational performance, while it should be flexible in the face of demands and changes of the environment, Fernandes (2013) proposes a research that investigates the feasibility of implementing a strategic plan, through the BSC methodology, in the department of economics and business administration UFLA (Federal University of Lavras). Through this investigation it is noticed that the BSC can also be used to measure the activities of the public sector.

In turn, Borges, Cabral and Petri (2014), in research directed specifically to the private higher education sector, suggest that high competition in this area justifies the need for such institution has strategies that allow for sound and sustainable management. Thus, the authors propose performance indicators from the perspective of customers, differentiated vision of the traditional studies that have centered their focus exclusively on the business context.

\section{METHODOLOGY}

In order to direct the search for rational the following question needs to be answered: How Brazilian HEls adopt and implement performance indicators in the control and measurement of its main activities? The responses may subsidize the discussions related to this theme.

This study was based on a deductive method of construction where a general and generic situation provides evidence to determine particular conceptions of an observed fact (CHIZZOTTI, 1995; MARCONI; LAKATOS, 2004). In turn, we used quantitative methods approach, as it is believed that they are more suited to what we intend to investigate this construct to mention, the application of performance indicators for the activities of HEls (higher education institutions).

For (KHUN, 1978), the choice of a quantitative approach brings to light some features. Regarding the ontology this study presents objective and natural reality with epistemology that makes it clear that no proximity between subject and object of study, the axiology is presented as value-free and static design methodology with which generalizations lead to predictions and explanations with reliability. An exploratory study is one that allows the construction of evidence, in order to make the 
DOI: 10.14807/ijmp.v6i2.261

research acquainted with the object in the context of its reality (PIOVESAN; TEMPORINI, 1995).

The procedures adopted this research leads to a documentary study. Regarding Cervo e Bervian (1978) this type of research is performed by contemporary or retrospective, scientifically authentic documents. To construct this study using electronic records of the leading private universities in Brazil containing information relating to the performance indicators of activities as research and extension, education, institutional management, financial management and information services.

This study is characterized as an interface in which the data were collected at a single time picturing a scenario at that time, which differs from longitudinal studies where data are collected over a long time (INEP, 2012).

For the preparation of the study, it was considered the 91 Brazilian private universities. Although only 43 organizations have in your electronic records, performance indicators of its main activities to meet the criteria for analysis it was considered appropriate to use the entire population. Data were obtained through a search on the web for all Brazilian private university websites. This search has focused on the search for indicators of institutional, financial and management performance.

How the selection criteria we used the following filters: a) the data analyzed should refer to activities for the year 2013; b) the data should be available on digital platforms specific to the institution performance indicators, ie, the analyzed data could not be taken from another source that was not the site of the institution.

To analyze the information obtained the data were organized, coded and interpreted by techniques specific to the objectives proposed analysis. The results that emerged from the research were placed in a straight sequence of significance in order to provide explanations that allow making inferences within an empirical reality (CHIZOTTI, 1995).

In order to enable a better understanding of the facts to be presented, this work was organized in four sections, in addition to this it is, evident. It begins with a critical review of the literature around the BSC and its application HEIs. 


\subsection{Results and discussion}

The use of performance indicators is a basic and essential tool for the management of an organization. When it comes to an HEls, the use of such measurement mechanisms becomes even more necessary in the face of the immensity of variables involved in its processes. In this section, we deal with aspects such as HEls assess essential factors to its dynamics, such as teaching and learning, institutional management, research and outreach, financial management and quality of communications services will be analyzed.

\subsection{Application of performance indicators}

Among the data obtained from the consultation to the web sites of Brazilian private universities emerged some considerations that, once quantified, allow realizing a more sound analysis and reliable foster discussions on the adoption and use of performance indicators. Figure 1 indicates through numerical reality of the use of such control and assessment tools in the context of the Brazilian private HEls data. The first feature shown in the graph is related to the amount of HEls, in fact; use performance indicators to monitor and evaluate their activities.

Amongst the 91 Brazilian private universities only 43 were used this tool. This number shows that less than half of total private universities in the country have a mechanism to measure that can provide them with information on the development of activities which they engage. Concerning the higher education institutions that adopt performance indicators in 27 of them this mechanism is employed in order to measure and control the activities of teaching - learning. In general, within this context the performance indicators are used to: quantify the satisfaction of students regarding curriculum guidelines; as the fitness for teaching project; as the creativity and commitment of teachers and many forms of assessment adopted by the institution. 
Figure 1: Application of performance indicators for the activities of HEls

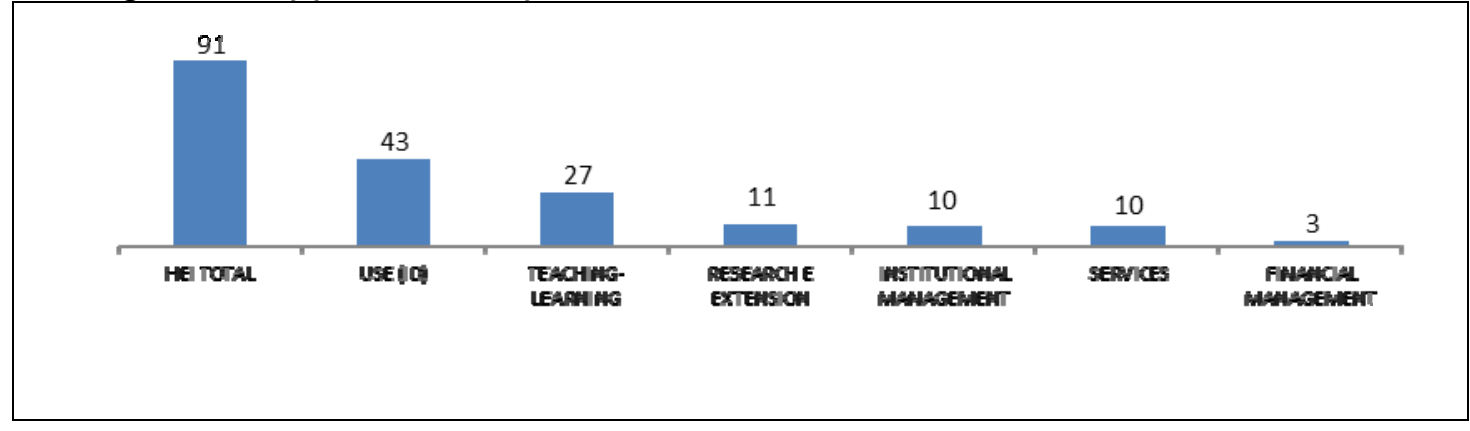

Amongst the 43 private universities using performance indices, 11 of them applies this tool in order to provide quantitative data for evaluating research and extension activities. The number of papers published in scientific journals or conference proceedings during the period is used to evaluate the research activity. In turn, the amount of actions developed to the community and its impacts are given for assessing the extension activities adopted by the organizations.

The number of private universities that use performance indicators to assess and analyze their institutional management was 10 . The institutional management was assessed by the ability of coordinators and directors generate positive results to the institution; however, the performance of organizations such as secretarial, library and laboratories are important to give satisfactory metrics institutional management of the university.

Similarly, it was found that 10 private universities use performance indicators to quantify and evaluate the quality of information services. Importantly, these institutions do not have the intention of quantifying the quality itself, since due to its subjective nature that action would be inaccurate. However, that measure is the effectiveness and outcomes associated with quality communication services, these are plausible quantification and analysis.

Finally, it was noted here that only 3 out of the 43 private universities that adopt performance indicators also measured its financial results. In those few opting for evaluation indexes such institutions financial results are demonstrated by means of balance sheets, income statement and statement of financial cash flow. Many institutions do not disclose their financial measures because it considers them private and restricted levels of analysis and verification of the exclusive managers of the institution. 


\subsection{Interrelationship of the activities developed by the HEls}

When analyzing the way in which HEls use performance indicators it was found that there is a tendency among these institutions to consider the activities, inseparably united within a dynamic execution context. For an activity to improve in a way suited to the above ideas, you must be satisfactorily fulfilled. Given these considerations it is proposed here is a functional performance model that provides the activities and performance indicators a dynamic and complementary character.

The proposed model (Figure 2) supports the view that the starting point of the flow that involves activities and performance indicators starts from the financial management of the institution. The proposal is that effective financial management, characterized by solvency of finance, it is essential to ensure the development of a private college.

In the context of the model, so that the second action, institutional management, to develop satisfactorily, the first should be within the standards of acceptance, these patterns observable through performance indicators as an income statement, balance sheet and cash flows.

Figure 2: Model of functional performance adopted in the study

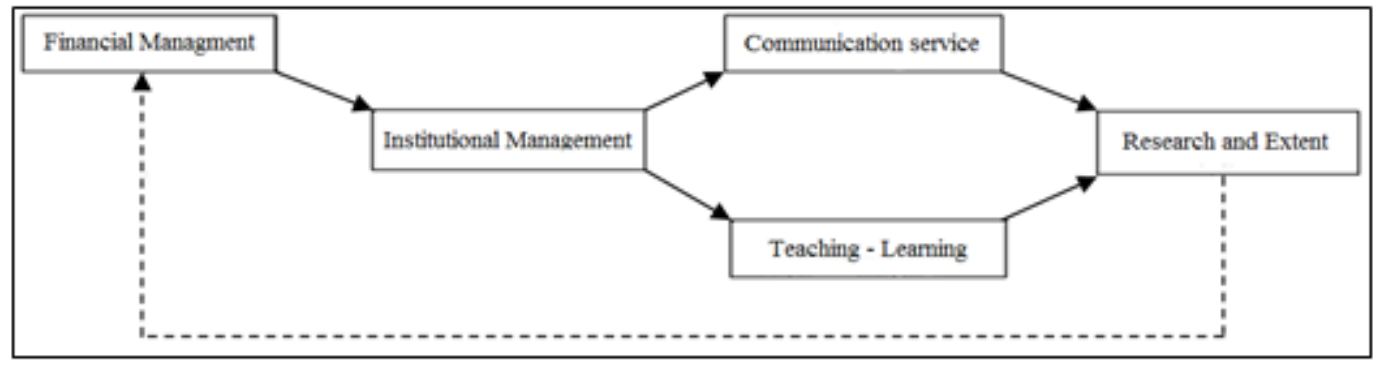

In turn, an appropriate institutional management- when coordinators and directors perform effectively in carrying out its functions, and resources like library, laboratories and departments are directed to the needs of students' quality learning activities, learning and services communication are good direct consequence.

These two combined functions converge in research and extension activities, ie, good internal communication tools, combined with incentives teaching - learning are fundamental to foster the adoption of research and extension activities by universities. In a private institution, the combination of all these activities when 
developed satisfactorily it provides financially profitable results. This feature justifies the character stream given the proposed model.

Performance indicators play a key role in this context since they act at the interfaces between one activity and another providing control and analysis of their results, which allows functions to develop dynamically and consistently on an intermittent and continuous flow.

\subsection{Effectiveness of performance indicators}

One question is relevant when analyzing the relationship between the use of performance indicators and the development of the institution. Until point the use of metering mechanisms and performance analysis influence in the effectiveness of implementation of activities in private HEls? This is a question still unresolved, since there are no data available that allows answering this question.

According to the results of the general index of courses (IGC) held in 2012, amongst the top 50 higher education institutions in Brazil only 3 were private (Pontifical Catholic University of Rio de Janeiro - PUC/RJ, Pontifical Catholic University of São Paulo - PUC/SP, Pontifical Catholic University of Rio Grande do Sul - PUC/RS, (INEP, 2012).

It appears that the aforementioned educational institutions use performance indicators, and it appears to be a relationship between the use of performance indicators and the effectiveness of their results. However, other organizations which favored the adoption and use of performance indicators of their activities were not even related to this classification.

Although there are indexes that qualify private HEls, none of them makes any inference to the impact of the performance indicators in these results. Thus, it appears that one cannot attribute the success of an educational institution to the fact possess indices measurement, while also cannot attribute their failure to lack of these indicators.

\section{FINAL REMARKS}

There is a considerable number of private institutions of higher education in Brazil, but few of them adopt performance indicators with numerical and statistical data covering core activities that in turn allow an analysis of the current situation and 
its evolution during a given time. This statement is guided by the presence or absence of performance indicators on the websites of these institutions.

For organizations that adopt performance indicators, most use these tools to measure and analyze the activities of teaching - learning. This preference is credited to the fact that these activities represent the main duty of an educational institution, so there are frequent actions in order to analyze and monitor the activities mentioned. Conversely, measurement and evaluation of investment income is the activity where educational institutions use less performance indicators.

In the context of the Brazilian HEls is perceived that the activities are joined in a continuous system of enforcement. This observation gives the dynamics of these activities the idea flow. It is noteworthy that for an action to improve, it is necessary that its antecedent has been carried out efficiently, and satisfactorily.

Even before the adoption of the relevant performance indicators and their importance in the development of metrics for analyzing the situation of the institution's teaching, there is still a gap to be filled in this issue that prevents this tool is linked to the success of these institutions or for arguing that their failure stems from its lack.

Thus, as a suggestion for further study identifies the possibility of building research that may correct this theoretical gap by means of a construct that correlates the adoption of performance indicators of the private HEls activities their effectiveness and development or their failure to involve the lack of such measurement mechanisms.

\section{REFERENCES}

BORGES, A. P. A. A.; CABRAL, E. V.; PETRI, S. M. (2014) Proposta de BSC para instituição de ensino superior privada sob a perspectiva de clientes. Revista

Cientifica do Alto Vale do Itajaí, v. 3, n. 3, p. set.

CAMPOS, J. A. (1998) Cenário balanceado: painel de indicadores para a gestão estratégica dos negócios. São Paulo: Aquariana.

CERVO, A. L.; BERVIAN, P. A. (1978) Metodologia Científica. São Paulo: McGrawHill do Brasil.

CHIZZOTTI, A. (1995) Pesquisa em Ciências Humanas e Sociais. São Paulo: Cortez. 
FERNADES, A. G. (2013) Balanced Scorecard aplicado a Administração Pública: uma Proposta de Planejamento Estratégico para o Departamento de Administração e Economia da Universidade Federal de Lavras. Dissertação (Mestrado em Gestão de Organizações Públicas). Lavras: Available in: http://repositorio.ufla.br/handle/1/1012. Acessed in: january 11. 2014.

INEP (2012) Instituto Nacionais de Estudos e Pesquisas, Available: http://www.publicacoes.inep.gov.br/resultados.asp?cat=6\&subcat=5. Acessed in: february 23. 2014.

KAPLAN, R. S.; NORTON, D. P. (1996) Linking the Balanced Scorecard to strategy. California Management Review. v. 31. p. 53-79.

KAPLAN, R. S.; NORTON, D. P. (1992) The balanced scorecard: measures that drive perfomance. Harvard Business Review. v. 70, p. 71-79.

KAPLAN, R. S.; NORTON, D. P. (1997) The balanced scorecard: translating strategy into action. Boston: Harvard Business school press.

KHUN, T. S. A. (1978) Estrutura das revoluções científicas. São Paulo: Perspectiva.

LIMA, C. R. M.; SOARES, T. C.; LIMA, M. A. A. (2012) Utilização do balanced scorecard em instituições de ensino superior. Revista de Informação Contábil, Porto Alegre, v. 6, n. 3, p.1-13, jul./set.

MACSTRAVIC, S. A. (1999) Really Balanced Scorecard. Health Forum Journal, v. 42, p. 64-67.

MARCONI, N. A.; LAKATOS, E. M. (2004) Metodologia Científica. São Paulo: Atlas.

O'NEIL, H. F.; BENSIMAN, E. M.; DIAMOND, M. A.; MOORE, M. R. (1999) Designing and implementing an academic scorecard, Change, v. 31, p. 32-40.

PAPINI, R. O.; SALLES, J. A. A.; VANALLE, R. M.; OLIVEIRA, R. D. (2011) Indicadores de Desempenho sob a ótica do Balanced Scorecard: estudo de caso numa empresa metalúrgica. Revista Científica Indexada Linkania Master, v. 1, n. 1, p. 1-11, st./out.

PHILBIN, S. (2011) Design and implementation of the Balanced Scorecard at a university institute. Measuring Business Excellence, v. 15, p. 34-45.

PIOVESAN, A.; TEMPORINI, E. R. (1995) Pesquisa exploratória: procedimento metodológico para o estudo de fatores humanos no campo da saúde pública. Revista de Saúde Pública, São Paulo, v. 29, p. 318-325.

PRADO, E. V.; BERTASSI, A. L.; FRANCISCHETTI, C. E.; PADOVEZE, C. L.; CARVALHO, A. D. (2013) Os desafios na implementação da controladoria estratégica nas Organizações. Caderno Profissional de Administração, v. 3, n. 2, p. 14-37.

SOUZA, G. M.; ALBUQUERQUE, A. C. L. (2012) A Importância Da Relação Entre Gestão Do Conhecimento Nas Organizações e o Balanced Scorecard Como Uma Vantagem Competitiva Na Gestão De Ativos Intagíveis. Revista Negócios em Projeção, Ceilândia, v. 3, n. 1, p. 14-30, abr. 
STEELE, J. (2001) Transforming the balanced scorecard into your strategy execution system. Manage, v. 1, p. 22-23.

VIEIRA, R. T. V.; PETRI, S. M. A. (2014) Contribuição do Balanced Scorecard nas Gestão Estratégica de um Escritório de Contabilidade. Pensar Contábil, Rio de Janeiro, v. 16 , n. 60 , p. 4-13, mai./ago. 